\title{
INCOME OVER FEED COST OF FATTENING LAMBS AT VARIOUS MARKET PRICES
}

\author{
Sondi Kuswaryan ${ }^{1}$, Cecep Firmansyah ${ }^{2}$, Hery Supratman ${ }^{3}$, Diky Ramdani ${ }^{4}$, and \\ Andre R Daud ${ }^{5}$, \\ ${ }^{1,2,5}$ Department of Social and Economics, The Faculty of Animal Husbandry, Unpad \\ ${ }^{3}$ Department of Nutrition and Feed Technology, The Faculty of Animal Husbandry, Unpad \\ ${ }^{4}$ Department of Animal Production, Universitas Padjadjaran \\ E-mail: sondi.kuswaryan@unpad.ac.id
}

\begin{abstract}
An economics experiment to study the values of Income over Feed Cost at various market prices of fattening sheep has been done at Sheep Experimental House of The Faculty of Animal Husbandry, Universitas Padjadjaran. About 63 heads of Garut growing lambs were fattened for 90 days and fed by corn silage and concentrate. Feed consumption and average daily gain (ADG) were measured and Income over Feed Cost was analyzed at different selling prices: 40,000 IDR/kg live weight at general market, 60,000 IDR/ $\mathrm{kg}$ live weight at Aqiqah Market, and 80,000 IDR/kg live weight at Qurban Market. The result showed that ADG of lambs was $122 \mathrm{~g} /$ head/day resulting in selling prices of 4,882 IDR/head/day for general market, 7,323 IDR/head/day for Aqiqah market, and 9,764 IDR/head/day for Qurban market. If average feed cost was 3,508 IDR/head/day, its Income over Feed Cost was 1.374 IDR/head/day for general market, 3,825 IDR/head/day for Aqiqah market, and 6,256 IDR/head/day for Qurban market. At non-feed cost of 1,921 IDR, there was a potential loss of 547 IDR/head/day if selling price was only 40,000 IDR/kg live weight. Breakeven point could be reached at selling price of 44,500 IDR/kg live weight. It is concluded that fattened lambs is not profitably sold to general market but can be profitably sold to Aqiqah and Qurban markets.
\end{abstract}

Keywords: Income over Feed Cost, fattening lambs, and market prices, 


\section{A. PRELIMINARY}

Livestock Statistics Data 2017 records sheep populations in West Java reaching 10,714,663, around 65.09 percent of the national sheep population, with a population increase trend of 6.73 percent from the previous year (Director General of Layoffs, 2017). This data shows that sheep are very important in supporting people's lives in West Java. In areas with very high intensity of agricultural land use, farmers breed sheep by means of straining, with a cut and carry pattern of grass feeding. In this maintenance pattern, sheep business contributes 29.15 percent to total farmer household income and the greater the number of sheep ownership, the greater the contribution tends to be (Kuswaryan and Firmansyah, 2017).

Most people's farms keep sheep oriented towards mixed activities between nurseries to produce lambs, as well as enlargement to be sold as a source of household income. In a maintenance pattern like this, the level of livestock productivity is relatively low, the length of maintenance becomes longer, and the number of livestock sold is relatively small, because of the length of time the maintenance is up to sellable livestock.

Until now at the level of sheep breeders, there have not been many efforts to optimize the growth potential of livestock to achieve the ideal selling weight in short maintenance periods through good feeding, and controlled maintenance, known as fattening. The pattern of caring for sheep through fattening is very important to study, due to the provision of good and controlled feeding requires relatively large feed costs compared to conventional maintenance patterns, although body weight gain can be obtained relatively high. The amount of feed costs has consequences for the relatively high selling price, so that the business does not suffer losses and even get profits.
In the current market structure of sheep in West Java, it is known that sheep prices differ between regular market prices, sheep prices for aqiqah and sheep prices for qurban. This price disparity provides sheep business opportunities to benefit. This study aims to determine the feasibility of keeping sheep with fattening patterns, in meeting market demand at varying price levels, namely at regular market prices, sheep market prices for purchasing puIDRoses for aqiqah and market prices to fulfill qurban holidays.

\section{B. MATERIAL AND METHODS}

This research was carried out using an economic experimental method, namely experimental research to obtain financial parameters in the intensive maintenance of the sheep fattening model.

\section{a. Materials and Research Tools:}

1. Livestock: The number of sheep used is 63, Garut sheep in general is around 9 months. The average initial body weight maintenance is $20.15 \mathrm{~kg} /$ head. At the beginning of the maintenance of the sheep the study was examined for health, so as not to be affected by parasites. Therefore sheep are bathed, shaved and given worm control treatment. Worm treatment is repeated every month during maintenance.

2. Feed: Feeding refers to the needs of sheep for growth. Therefore sheep are weighed faithfully in the moon. The feed provided consisted of concentrated feed as much as 0.8 $\mathrm{kg} /$ head / day, coupled with silage of fresh corn trees as much as $0.80 \mathrm{~kg} / \mathrm{head} / \mathrm{day}$. The amount of feed is given twice. Morning giving is done at $08.00 \mathrm{WIB}$ and in the afternoon at $16.30 \mathrm{WIB}$.

3. Cage: Sheep is placed in a colony cage, enclosure space with a measurement of 1.85 . x $2.25 \mathrm{~m}, 7$ sheep filled. Sheep were placed in three maintenance blocks, each with 21 tails. 
4. Drinking water: Provided in ad libitum, and replaced every day.

5. To maintain a stable microclimate condition, especially from wind, the cage is closed at night and opened after the sun shines into the cage.

Prices and Costs for Maintenance of Sheep

1. The price of sheep used in this study uses the average price of sheep in the regular market of IDR. 40,000 / kg of live weight, market price for the puIDRose of purchasing aqiqah IDR. 60,000 / kg live weight and market price for the puIDRose of qurban. amounting to IDR. 80,000 / kg body weight.

2. Feed Price: The type of feed used in this study consisted of silage feed of fresh corn trees and concentrate feed. The price of fresh corn silage is IDR. 1,000 per $\mathrm{kg}$, while the price of concentrate is IDR. 2,800 per kg, at the level of protein content of around 13-14 percent.

3. Fixed Costs and Operational Costs.

In addition to feed costs, sheep fattening businesses need operational costs and depreciation costs from building cages and purchasing durable equipment. In addition, costs incurred for investment puIDRoses are needed. In detail the financing components besides the cost of feed, can be seen in Table 1.

Table 1. Non-Feed Costs and Operational Costs in Model Maintenance Sheep Fattening.

\begin{tabular}{|c|c|c|c|}
\hline No & $\begin{array}{l}\text { Cost } \\
\text { Componen }\end{array}$ & Satuan & Value \\
\hline & $\begin{array}{l}\text { sheepfold } \\
\text { Depreciation }\end{array}$ & IDR/head/day & 342 \\
\hline 2. & $\begin{array}{l}\text { Equipment } \\
\text { Depreciation and } \\
\text { electric }\end{array}$ & IDR/head/day & 169 \\
\hline 3. & Labor & IDR/head/day & 500 \\
\hline 4. & $\begin{array}{l}\text { Medicine and } \\
\text { health }\end{array}$ & IDR/head/day & 444 \\
\hline 5. & $\begin{array}{l}\text { Investment loan } \\
\text { interest }\end{array}$ & IDR/head/day & 465 \\
\hline & Total & IDR/head/day & 1.921 \\
\hline
\end{tabular}

\section{RESULT AND DISCUSSION a. Food Consumption And Weight Gain}

Feeding in this study refers to the need for sheep to grow and develop, therefore the amount of administration is adjusted to increase the body weight of the sheep. The average amount of feed consumption during maintenance for silage is 797.70 grams / head / day and for concentrates as much as 741.95 grams / head / day. The amount of this gift is relatively small in quantity compared to feeding provided on people's sheep farms. Kuswaryan et al (2016) obtained the amount of grass feed on people's sheep farms on average as much as $6.03 \mathrm{~kg} /$ head / day.

At the average level of feeding given in this study, the response of body weight gain averaged 122.00 grams / head / day. Similar results were reported by Herianti and Prawirodigdo (2010), that improvement in rationing on thin-tailed sheep gave a good influence on daily body weight gain, in grass-fed sheep as a single ration resulted in body weight gain of 36.67 grams / head / days, in the ration added with cassava yams body weight increased to 71.78 grams / head / day, with the addition of cassava, bran, tofu and gliricidia leaves the sheep added to 107.89 grams / head / day. Yusran et al. (2001) reported his research on pre-stocked fat tailed sheep, giving $5 \mathrm{~kg} /$ head / day of field grass basal feed plus 500 grams of concentrate, resulting in daily body weight gain of 130 grams / head / day. These results prove that by providing good feed, sheep responds to higher body weight compared to maintenance given grass basalt feed. According to Beigh et al (2017), in ruminant animals complete feed (such as fattening feed) will make rumen fermentation stable, further influencing the improvement of feed nutrient utilization. These results provide hope for greater utilization of the potential use of agro-industrial byproducts, agricultural waste products, and other conventional feed potential for ruminant feed, both for the puIDRose of 
increasing productivity and conserving production costs.

\section{b. Income Over Feed Cost}

In intensive care sheep, the variable cost of feed takes the largest portion of the cost compared to other cost components, generally in the range of $60-80 \%$ of the total cost. Therefore, if the cost component of this feed can be fulfilled, the opportunity to get a business profit becomes quite large. From a number of receipts as a result of the sale of sheep, if deducted by the value of costs incurred for feed, it will generate an income over feed cost (IOFC) value. The amount of IOFC besides being determined by the amount and price of feed, is also very sensitive to the price of the product, the greater the value of the product sold, the greater the potential of IOFC to be able to pay the fixed costs and other variable cost components.

In the structure of the sheep market in West Java, the price of sheep is strongly influenced by the puIDRose of using lamb. In the daily market where lamb is used for daily consumption (households or processors), the price of live sheep is valued at the price of female sheep at a price of IDR. 40,000.00 per kg of weight, for the benefit of aqiqah rams valued at IDR. 60,000.00 per kg live weight, while the most expensive, the price of ram occurs in the qurban season, with an average price of IDR. $80,000.00$ per $\mathrm{kg}$ of live weight. At various price levels that occur on the market, the fattening IOFC values can be seen in Table 2.

The IOFC value obtained in this study shows a positive value, meaning that the product sales are still able to pay for feed costs. Provision of feed according to the needs for optimal growth was able to provide support for positive IOFC achievements. The same results have been reported by Munir and Kardiyanto (2015) who report the results of their research that supplementary feeding on fattening sheep significantly affects body weight gain and feed efficiency and will increase the value of income over feed cost.

Table 2. IOFC Values at Various Price Levels in the Lamb Market

\begin{tabular}{|c|c|c|c|}
\hline \multirow[t]{2}{*}{ Sheep Fattening } & \multicolumn{3}{|c|}{$\begin{array}{c}\text { Price Levels } \\
\text { (IDR/Kg/live weight) }\end{array}$} \\
\hline & 40.000 & 60.000 & 80.000 \\
\hline \multicolumn{4}{|l|}{ Fattening Block I } \\
\hline daily gain Value (IDR/head/day) & 4.722 & 7.082 & 9.443 \\
\hline Feed Cost (IDR/head/day) & 3.410 & 3.410 & 3.410 \\
\hline Income Over Feed Cost (IOFC). (IDR/head/day) & 1.312 & 3.672 & 5.033 \\
\hline \multicolumn{4}{|l|}{ Fattening Block II } \\
\hline daily gain value (IDR/head/day) & 4.709 & 7.063 & 9.418 \\
\hline Feed Cost (IDR/head/day) & 3.526 & 3.526 & 3.526 \\
\hline Income over Feed Cost (IOFC). (IDR/head/day) & 1.183 & 3.537 & 5.892 \\
\hline \multicolumn{4}{|l|}{ Fattening Block III } \\
\hline Daily gain value (IDR/head/day) & 5.216 & 7.823 & 10.431 \\
\hline Feed Cost (IDR/head/day) & 3.589 & 3.589 & 3.589 \\
\hline Income over Feed Cost (IOFC). (IDR/head/day) & 1.627 & 4.243 & 6.842 \\
\hline \multicolumn{4}{|l|}{ Average } \\
\hline Daily gain value (IDR/head/day) & 4.882 & 7.323 & 9.764 \\
\hline Feed Cost (IDR/head/day) & 3.508 & 3.508 & 3.508 \\
\hline Income over Feed Cost (IOFC) (IDR/head/day) & 1.374 & 3.815 & 6.256 \\
\hline
\end{tabular}


The financial prospect of a sheep fattening pattern designed to gain huge profits, all IOFC values show positive numbers. A positive IOFC value is expected to be able to pay for short-term expenditures, among others, the maintenance workforce component at home. Other cost components are relatively small, for example for treatment and others. In its operations, routine labor activities in cages in fattening patterns are relatively very light, because they only allocate work for feeding and drinking, while other activities are non-routine such as epilation, bathing or treatment of sheep. In the fattening pattern designed in this study, one male working day (HKP) can handle around 250 sheep per day. In the long run, the IOFC value must also be able to cover the depreciation value of the fixed cost component. The fixed cost component that has a large enough value is the depreciation of cages and equipment. The value of these fixed costs will be smaller in line with the increasing number of pets run.

The profit potential can be seen by comparing the IOFC values with the cost components not included in IOFC (Table 1). At an average daily body weight gain of 122 grams / head / day and IOFC value in Table 2, each of IDR 1,374, IDR 3,815 and IDR 6,256 at the sheep price level of IDR 40,000, IDR. 60,000 and IDR. 80,000 / kg $\mathrm{BW}$, then the potential for business feasibility can be seen in Table 3 .

Table 3. Potential Benefits of Feedlot Sheep at Various Sheep Prices

\begin{tabular}{lccc}
\hline $\begin{array}{l}\text { Price Levels } \\
\text { (IDR/Kg/live } \\
\text { weight) }\end{array}$ & $\begin{array}{c}\text { IOFC } \\
\text { (IDR/head/day) }\end{array}$ & $\begin{array}{c}\text { Non IOFC } \\
\text { (IDR/head/day) }\end{array}$ & $\begin{array}{c}\text { Profit } \\
\text { potency } \\
\text { (IDR/head/ } \\
\text { day) }\end{array}$ \\
\hline 40.000 & 1.374 & 1.921 & -547 \\
60.000 & 3.825 & 1.921 & 1.904 \\
80.000 & 6.256 & 1.921 & 4.335 \\
\hline
\end{tabular}

Reviewing Table 3, it turns out that at the market price level of IDR. 40,000 / Kg live BB and the average body weight gain of 122 grams / head / day, it has not been able to cover the total business costs. In these conditions, a new break even point will be reached at a minimum selling price of IDR $44,500 / \mathrm{Kg}$ live BB. Thus, the sheep fattening business is only feasible if the selling price of sheep is above IDR 44,500 / Kg live $\mathrm{BB}$, meaning that the fattening sheep does not support the financial feasibility of the business if it is sold on the regular market. The profits of the fattening sheep business will benefit the business, if it is sold to meet the needs of aqiqah or the needs of the Eid qurban.

\section{CONCLUSION}

The business of fattening sheep has a prospect to run, especially fattening products sold to meet market demand for aqiqah or fulfill the market for qurban idul. The application of the sheep fattening model in the community can be done after farmers understand and are able to master the zoo-technical fattening and financial support is needed to cover relatively high feed costs compared to traditional maintenance patterns.

\section{REFERENCES}

Herianti, Idan S. Prawirodigdo (2010), Introduksi Formula Untuk Perbaikan Kualitas Pakan Dalam Usaha Penggemukan Domba Di Desa Pringsurat Kabupaten

Temanggung (Introduction of Formula for Improving Diet Quality in The Sheep Fattening Farm at Pringsurat Village of Temanggung District). Seminar Nasional Teknologi Peternakan dan Veteriner 2010.

Kuswaryan, S., C. Firmansyah dan U. Hakimah. (2016). Dampak Kesertaan Peternak Sebagai Anggota Koperasi Terhadap Kinerja Usahaternak Domba : Kasus Pada Koperasi Peternak Serba Usaha Riung Mukti Kecamatan Kalapanunggal Kabupaten Sukabumi - Jawa Barat. Seminar Nasional Pengembangan Peternakan Berkelajutan ke-8. Jatinangor, 16 Nov 20016 
Kuswaryan, S dan C. Firmansyah, 2017. Jumlah Peliharaan dan Kebutuhan Tenaga Kerja pada Usahaternak Domba sebagai Sumber Pendapatan Utama Keluarga. Seminar Nasional Pengembangan Peternakan Berkelanjutan ke-9. Desember 2017. UNPAD Bandung.

Beigh, Y.A., A. M. Ganai and Haidar Ali Ahmad, 2017. Prospects of complete feed system in ruminant feeding: A review. Veterinary World, EISSN: 2231-0916
Available atwww.veterinary world.org/ vol.10/April-2017/10.pdf

Yusran, M.A., L. Affandhy, aryogi, D. Hardini dan E. Yogawati. 2001. Pengkajian paket teknologi pemeliharaan domba ekor gemuk induk pasca beranak pada kondisi ternak domba rakyat di Jatim. Pros. Seminar dan Ekspose Teknologi. BPTP, Jatim. Malang 11 - 12 September 2001. Pusat Sosial Ekonomi dan Kebijakkan Pertanian, Bogor. 